\title{
ROLE OF SOME FERMENTATIVE PARAMETERS FOR MICROBIAL TRANSFORMATION OF PROGESTERONE TO CORTEXOLONE AND/OR HYDROCORTISONE.
}

(Received: 23. 1. 2012)

\author{
By \\ H. A. A. El Menoufy, M. S. Shafei, M. M. Gharieb* and R. A. Abd El Aal \\ Natural and Microbial Products Chemistry Department, National Research Center \\ * Botany Department, Faculty of Science, Menoufia University.
}

\begin{abstract}
Four strains belonging to the genus Curvularia were tested for their ability to transform progesterone to cortexolone and hydrocortisone. Curvularia lunata RCMB 019002 showed the greatest bioconversion efficiency $(29.64 \%)$. In a medium containing (g/l); yeast extract 4 and malt extract 20 , the substrate was converted after $48 \mathrm{~h}$ to cortexolone and cortisol. The maximum bioconversion efficiency (37. $72 \%$ ) was recorded when phosphate buffer was used at $\mathrm{pH}$ 7.0. The transformation pattern of progesterone markedly affected by the inoculum size and culture age. The bioconversion efficiency increased $(63.2 \%)$ when the substrate concentration was $5 \mathrm{mg} / 50 \mathrm{ml}$ fermentation medium. The addition of the surface active agents Tween 60 and Tween 80 to the medium at concentrations of $100 \mu l, 50 \mu l$, respectively increased the bioconversion efficiency (66.70 and $68.64 \%$, respectively). Among the tested amino acids, L-asparagine enhanced the formation of cortexolone and cortisol.
\end{abstract}

Key words: biotransformation, cortexolon, cortisol, Curvularia lunata, Progesterone.

\section{INTRODUCTION}

Introduction of a hydroxyl group to a steroid molecule at position 11 is one of the most important steps in the preparation of various physiologically important steroidal derivatives and drugs (Manosroi et al. ,2008). In microbial hydroxylations, hydroxylase enzyme can introduce a hydroxyl group to various positions of the steroid molecule that are generally chemically inaccessible. Several positions in the steroid molecules can be hydroxylated by various microbial strains such as Curvularia lunata (Templeton et al., 1987), Mucor griseocyanus (Krasnova et al., 1987), Trichoderma spp. (ElKadi and Mostafa, 2004), A .niger (Fouad et al., 2009) and Rhizopus spp. (Martin, 2010). The $11 \alpha$, $11 \beta$, and $16 \alpha$-hydroxylations have been achieved in the steroidal drug production by microbial transformations at high yield and controlled costs (Farooq et al.,1994, Vitas et al.,1994 ).

Generally, steroidal drugs have therapeutic advantages such as increased potency, longer half lives in the blood stream and reduced side effects (Mohamed and Abd El- Hadi, 2010). Manufactured steroidal compounds have a wide range of therapeutic purposes, namely as antiinflammatory, immunosuppressive, progestational, diuretic, anabolic and contraceptive agents (Fernandes et al., 2003; Stephanie, 2006).
The aim of the present work was to evaluate the enzymic $11 \beta$ hydroxylation of progesterone to cortexolone and cortisol by Curvularia lunata RCMB 019002 under different biochemical conditions.

\section{MATERIALS AND METHODS}

\subsection{Microorganism and medium}

Microorganisms used in this study (Curvularia clavata RCMB 019003, Curvularia lunata 59 and Curvularia lunata RCMB 019002) were kindly obtained from the Regional Centre of Fungi, AlAzhar University while Curvularia lunata 2437 was taken from Assuit University Mycological Center (AUMC) and maintained on potato dextrose agar medium (PDA) gl :PDA 39, agar 8. The fermentation medium contained $(\mathrm{gll})$ : malt extract 20, yeast extract 4 at initial $\mathrm{pH} 6$.

\subsection{Chemicals}

The steroids used in this work namely: cortexolone (Reichstein's Substance S; 17 $\alpha$, 21dihydroxy-pregn-4-ene-3,20-dione), cortisol (hydro-cortisone; Kendall's compound F; 11 $17 \alpha, \quad 21$-trihydroxy-pregna-1,4-diene-3,20-dione) and progesterone were provided by Sigma Company, USA. Potato dextrose agar, yeast extract and Bacto peptone were purchased from Difco Laboratories (USA). 


\subsection{Bioconversion of progesterone by Curvularia lunata RCMB 019002}

The organism was grown in $50 \mathrm{ml}$ aliquots of the bioconversion medium using 250 Erlenmeyer flasks and each was inoculated with $5 \mathrm{ml}$ spore suspension, incubated at $28 \pm 2^{\circ} \mathrm{C}$ for $48 \mathrm{~h}$ under shaking conditions (150 rpm).

The synthesis of the enzymes, 11ßhydroxylase, $17 \alpha-$ hydroxylase and 21 hydroxylase were induced by the addition of progesterone $(0.5 \mathrm{mg} / 50 \mathrm{ml}$ medium dissolved in $0.5 \mathrm{ml}$ absolute ethanol) for 24h. The bioconversion medium containing the fungal cells was supplemented with $10 \mathrm{mg}$ of progesterone dissolved in $1 \mathrm{ml}$ absolute ethanol and the fermentation was continued for $48 \mathrm{~h}$.

\subsection{Analysis of steroid conversion}

\subsubsection{Extraction and qualitative determination} of the transformation products

At the end of the transformation period, $100 \mathrm{ml}$ chloroform were added to each flask containing free fungal cells. However, on using the immobilized cultures, chloroform was added to the filtrate. The extraction was repeated twice to ensure that none of the transformation products was left. The combined chloroform extracts were dried over anhydrous sodium sulphate and evaporated to dryness in vacuo to give semi - solid residue (test material), (Parasckiewicz and Dlugoński, 1998).

The steroid substances present in the test material were identified by thin-layer chromatography (TLC) in comparison with authentic steroid references, using the following solvent system: benzene: ethyl acetate: acetone (80: $20: 10, \mathrm{v} / \mathrm{v})$. The following colour reagent:Lieberman-Burchard: $5 \mathrm{ml}$ concentrated sulphuric acid were added slowly while cooling to $50 \mathrm{ml}$ absolute ethanol then $5 \mathrm{ml}$ acetic anhydride were dropped while cooling on the mixture (Waldi, 1965) this was used so spots appeared after heating the plates at $110^{\circ} \mathrm{C}$ for $5 \mathrm{~min}$ in a dry oven. The thin layer chromatographic pictures of the different steroids were encountered during the bioconversion process and compared with authentic samples.

\subsubsection{Quantitative analysis}

The tested material (total transformation mixture) was dissolved in a measured volume (5ml chloroform) and applied on TLC plate. The plate was then developed with the solvent system benzene : ethylacetate: acetone (80:20:10; v/v). The authentic steroid references dissolved in the same solvent were also applied as a narrow band along side the test material streak. The narrow band of the steroid references was sprayed with the colour reagent, while the rest of the plate (test material) was covered. The area at the same level of each steroid reference was marked, scrapped from the plate and quantitatively eluted with chloroform. The extract was separated by filteration and evaporated to dryness on a water bath. The residue was dissolved in $8 \mathrm{ml}$ of the colour reagent composed of concentrated sulphuric acid: ethanol $(45: 55 ; \mathrm{v} / \mathrm{v})$. The obtained solutions were separetly heated for $20 \mathrm{~min}$ in a water bath, cooled and read at $420 \mathrm{~nm}, 515 \mathrm{~nm}$ and $445 \mathrm{~nm}$ for cortisol, cortexolone and progesterone, respectively. The exact concentrations were calculated from prepared standard curves.

\subsection{Optimization of transformation parameters} 2.5.1. Screening for the most active organism

The four fungal strains were screened for their ability to transform progesterone to cortexolone and cortisol . The experimental microorganisms were cultured on the medium containing $(\mathrm{g} / \mathrm{l})$ : malt extract 20 and yeast extract 4 . Progesterone(10mg) was added and the transformation period was continued for $48 \mathrm{~h}$. The steroid products were extracted and the qualitative and quantitative analyses were made.

\subsubsection{Bioconversion time course}

Inoculated flasks containing fermentation medium $(50 \mathrm{ml})$ were shaken at $30^{\circ} \mathrm{C}$ for $48 \mathrm{~h}$ after which they were supplemented with $10 \mathrm{mg}$ of progesterone, the samples were then collected for analysis at 24, 48, 72, 96 and $120 \mathrm{hr}$.

\subsubsection{Bioconversion medium}

The most potent microorganism was cultivated into five different media, each supplemented with $10 \mathrm{mg} / 50 \mathrm{ml}$ media of progesterone dissoloved in $1 \mathrm{ml}$ of absolute ethanol. The inoculated media were incubated for $48 \mathrm{~h}$ under shaking conditions at $28^{\circ} \mathrm{C}$, the initial $\mathrm{pH}$ was adjusted to 6 in all cases of the necessary analyses were carried out. The media utilized included $(\mathrm{g} / \mathrm{l})$ Medium I : glucose 40; peptone 1; yeast extract 1 ; $\mathrm{MgSO}_{4} .7 \mathrm{H}_{2} \mathrm{O}$ 1; potassium dihydrogen phosphate 0.74; L.asparagine 0.7 and $\mathrm{pH}$ adjusted at 6 . Medium II consists of (g/l): malt extract 20; yeast extract $4, \mathrm{pH}$ adjusted at 6 . Medium III consists of (g/l) potato 300; glucose 20, $\mathrm{pH}$ adjusted at 5.6. Medium IV consists of $(\mathrm{g} / \mathrm{l})$ yeast extract 5 ; bacto peptone 5; glucose 20; sodium chloride5; potassium dihydrogen phosphate $5 ; \mathrm{pH}$ adjusted at 6. Medium V consists of $(\mathrm{g} / \mathrm{l})$ : soya flour 5; yeast extract 5; potassium dihydrogen phosphate 5; sodium chloride 5; glucose 20 and $\mathrm{pH}$ adjusted at 6. 


\subsection{4. pH Value}

The effect of $\mathrm{pH}$ was studied either by adjusting the fermentation medium ( No II ) initially before autoclaving with (M NaoH or M $\mathrm{HCl}$ ( $\mathrm{pH}$ 5.5- 8) or with phosphate buffer system after autoclaving in all cases. Flasks were inoculated, incubated under shaking conditions 48 $\mathrm{h}$ at $28^{\circ} \mathrm{C}$, and then progesterone $(10 \mathrm{mg}$ ) was added and the transformation period continued for $48 \mathrm{~h}$.

\subsubsection{Inoculum size}

Aliquots (50ml each) of medium II were inoculated with different amounts $(1-20 \mathrm{ml})$ of spore suspension prepared from a 7- day old culture of the tested organism. The flasks were agitated at $150 \mathrm{rpm}$ for $48 \mathrm{~h}$ at $28^{\circ} \mathrm{C}$, supplemented with $10 \mathrm{mg}$ progesterone and the fermentation continued for $48 \mathrm{~h}$.

\subsubsection{Culture age}

Aliquots (50ml each) of medium II were inoculated with $15 \mathrm{ml}$ inoculums $(0.178 \mathrm{~g}$ of cell dry weight) of C.lunata RCMB 019002 , incubation for 1, 2, 3, 5 and 7 days under shaking conditions (10mg each) of progesterone was separately added to the culture at each period, the transformation period was continued for $48 \mathrm{~h}$ and the necessary analyses were carried out.

\subsubsection{Substrate concentration}

The substrate (progesterone) was added to the medium as separate batches of $(5,7.5,10,15$ and $20 \mathrm{mg} / 50 \mathrm{ml}$ after $48 \mathrm{~h}$ and the necessary analyses were carried out.

\subsubsection{Surface active agents}

The effect of Tween 60 and Tween 80 were studied by supplementing the transformation medium with the composed at different concentrations $(50,100,150 \mu \mathrm{l} / 50 \mathrm{ml}$ medium). The transformation period continued for $48 \mathrm{~h}$.

\subsubsection{Amino acids}

The effect of the amino acids L-asparagine, L.leucine and cysteine was tested where either was added individually at the concentration of $0.5 \mathrm{mg} / 50 \mathrm{ml}$ medium. The tested amino acids were sterilized and supplemented to the medium under aseptic conditions at time of substrate addition.

\section{RESULTS AND DISCUSSION}

\subsection{Screening for the most active organism}

The results of the ability of different fungal cultures to carry out the $11 \beta$ hydroxylation and/or $17 \alpha$ hydroxylation and/or 21 hydroxylation of progesterone to cortexolone and cortisol are given in Table (1). The amount of the formed cortexolone and cortisol with the active strain was further assayed in qualitative bases, it is evident in Fig.(1) that the different organisms are versatile in their potentiality to convert progesterone to cortexolone and cortisol. A comparable cortexolone \& cortisol yield was obtained with all of the different fungi used. Among the tested fungal isolates C.lunata RCMB 019002 was clearly able to perform the hydroxylations reactions $(29.64 \%)$. These results are in close agreement with the findings of others (Vitas et al. 1995, Manosroi et al. 2008,). Meggs et al. (1990) reported that steroid hydroxylations by filamentous fungi including $11 \beta$-hydroxylation are economically important for the production of corticosteroids. This may be due to the fact that the enzymes responsible are from the P450 superfinly (Nelson et al., 1993).

Table (1): Thin layer chromatographic picture of the different steroids encountered during the transformation processes.

\begin{tabular}{|c|c|c|c|}
\hline \multirow{2}{*}{ Compound } & $\mathbf{R}_{\mathbf{f}} \times 100$ & \multicolumn{2}{|c|}{$\begin{array}{c}\text { Colour with } \\
\text { Liebermann-Burchard } \\
\text { Reagent in }\end{array}$} \\
\cline { 2 - 4 } & $\begin{array}{c}\text { With } \\
\text { solvent } \\
\text { system* }\end{array}$ & Day light & $\begin{array}{c}\text { UV } \\
\text { fluorescence }\end{array}$ \\
\hline Cortexolone & 25 & Orange & Deep yellow \\
\hline Cortisol & 6 & $\begin{array}{c}\text { Pale } \\
\text { brown }\end{array}$ & $\begin{array}{c}\text { Green } \\
\text { yellow }\end{array}$ \\
\hline Progesterone & 68 & Brown & Brick \\
\hline
\end{tabular}

*Solvent system used: Benzene: ethylacetate: acetone $(80: 20: 10, v / v)$

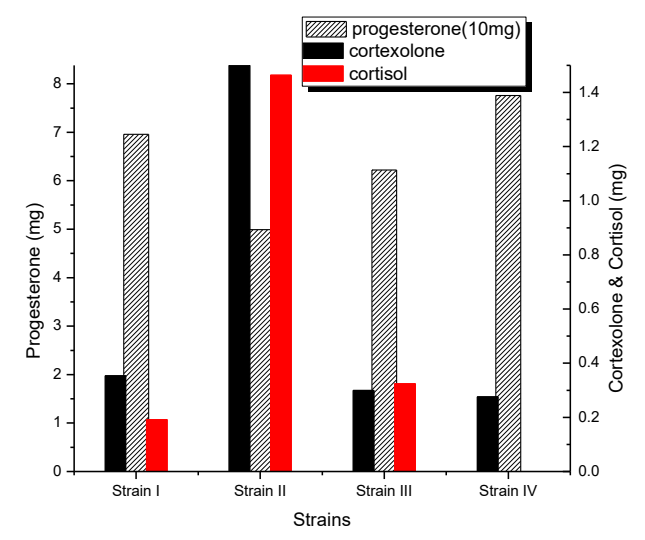

Fig.(1): Screening for the ability of different tested fungi to transform progesterone to cortexolone and cortisol.

Strain I Curvularia clavata RCMB 019003

Strain II Curvularia lunata RCMB 019002

Strian III Curvularia lunata 59

\subsection{Bioconversion time course}

The transformation of progesterone with the tested organisms was further analyzed at different intervals of the fermentation process. Optimal transformation period for cortexolone and cortisol 
production was attained after $48 \mathrm{~h}$ when the yield reached about $(1.5,1.4 \mathrm{mg}$ of cortexolone \& cortisol), respectively Fig.(2). As a result of this experiment, the study of progesterone transformation by the experimental organism was carried after $48 \mathrm{~h}$; similar results were obtained by El Kadi and Mostafa,( 2004 )and Mohamed and Abd El Hadi ,( 2010).

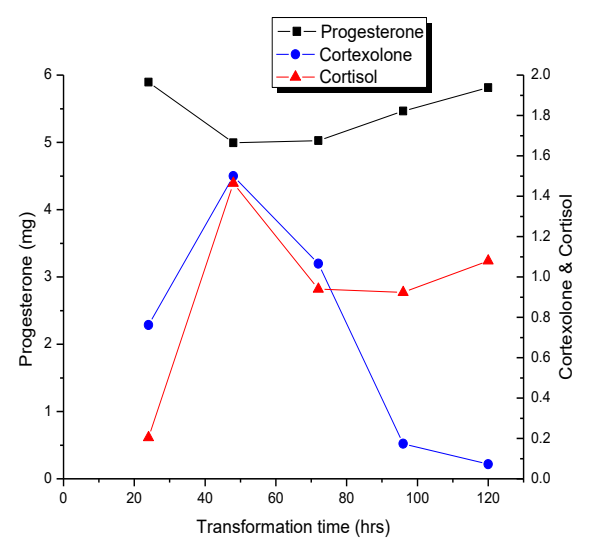

Fig. (2): Effect of the transformation time course of progesterone by Curvularia lunata RCMB019002.

\subsection{Bioconversion medium}

As an orientation step, selection of the proper fermentation medium for the performance of the hydroxylation of progesterone by Curvularia lunata RCBM was carried out.

Five media of different composition were tested for the propagation of the experimental organism catalyzing the transformation of progesterone. In all media tested, progesterone was added after $48 \mathrm{~h}$ incubation.

The results shown in Fig.(3) indicated that medium II (Voigt et al., 1993) proved to be the most favorable for the transformation of progesterone to cortexolone and cortisol .

The superiority of this medium may be due to the presence of yeast and malt extracts. The latter constituents may provide the necessary growth factors as well as factors and cofactors stimulating the biotransformation of progesterone to cortexolone and cortisol. Fouad et al. (2009) also reported a similar medium.

\subsection{Effect of $\mathrm{pH}$ of the fermentation medium}

The role of the initial $\mathrm{pH}$ or buffered $\mathrm{pH}$ values of the fermentation medium on the transformation of progesterone was conducted by adjusting, the $\mathrm{pH}$ of different aliquots of medium II with $1 \mathrm{~N}$ of $\mathrm{HCl}$ or $\mathrm{NaOH}$ to cover $\mathrm{pH}$ ranges from 5.5to8. The highest bioconversion rates of progesterone were obtained at the $\mathrm{pH}$ range of 6-7 by using either unbuffered or buffered media. The bioconversion process was markedly retarded at $\mathrm{pH}$ below 6 or above 7.0. Acidic media below 5.5, or alkaline above 8 seemed unfavourable for hydroxylation reaction. The control of the reaction with buffer solution is essential for investigating the role of

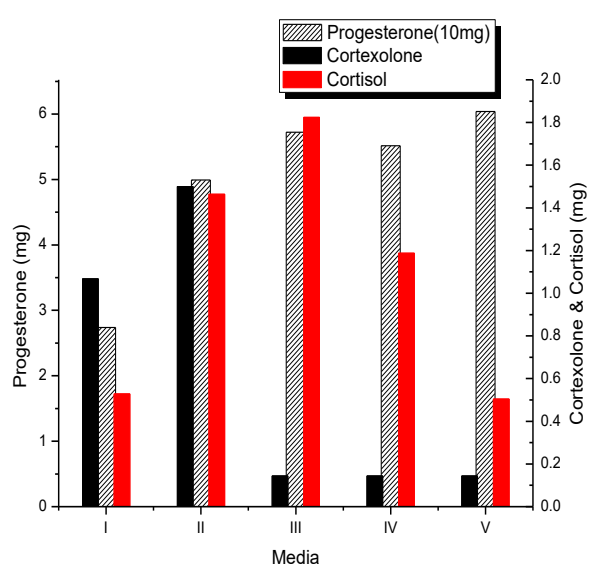

Fig.(3): Role of chemical composition of fermentation medium on progesterone bioconversion to cortisol and cortexolone.

$\mathrm{pH}$ value of the medium . Therefore, the aliquots medium II were adjusted to $\mathrm{pH}$ 5.5-8 using phosphate buffer. Data in Fig. (5) showed that cortexolone and cortisol yield were the highest at $\mathrm{pH} 7.0$ similar to that obtained using initial $\mathrm{pH}$ (Fig. 4). Chinckolkar et al. (1995) found that $\mathrm{pH}$ 6.0 was the best optimal for progesterone biotransformation using Cunninghamella blakseleana NCIM 687.

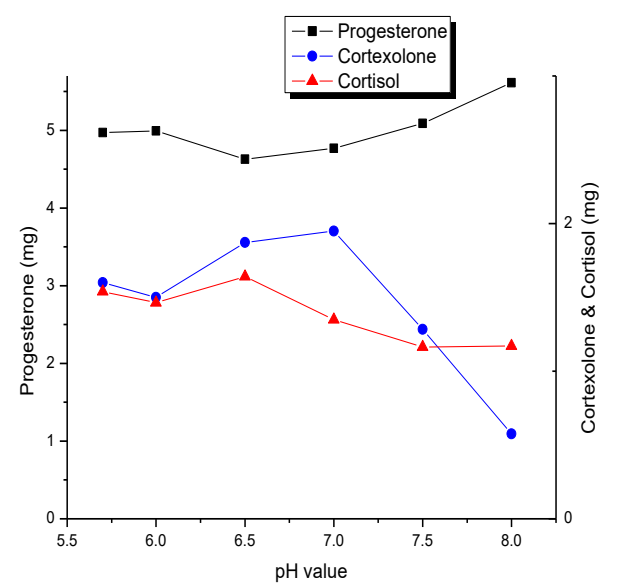

Fig. (4): Transformation of progesterone by Curvularia lunata RCMB019002 as influenced by the initial pH value of the fermentation medium. 


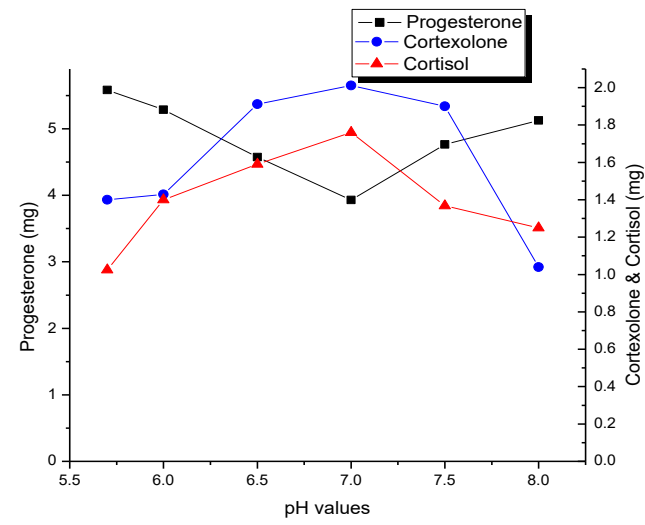

Fig.(5): Transformation of progesterone by Curvularia lunata RCMB019002 grown on the fermentation medium adjusted with phosphate buffer to different $\mathrm{pH}$ values.

\subsection{Effect of inoculum size on progesterone bioconversion}

A maximum cortexolone and cortisol yield (2.860 and $2.690 \mathrm{mg}$ respectively) were obtained by using $15 \mathrm{ml}$ of cell suspension equivalent to $0.1787 \mathrm{~g}$ of cell dry weight (Table 2).These results were found to be in contrary with EL Refai et al. (1969) and Fouad et al. (2009) who used $2 \mathrm{ml}$ cell suspension of Rhizopus nigricans and Asperigillus niger respectively to transform progesterone to 11 $\alpha$-hydroxyprogesterone.

\subsection{Effect of culture age on progesterone} biotransformation

It was evident that, the bioconversion of progesterone by Curvularia lunata RCMB 019002 was affected by different growth ages. Table (3) showed that higher cortexolone and cortisol yield $(58.65 \%)$ was formed after $48 \mathrm{~h}$ old cultures. These results run parallel with those reported by many authors (Mohamed and Abd El Hadi ,2010;

El Kadi and Mostafa, 2004).

On the other hand, Fouad et al., (2009) found that 10 days were the best culture age for the biotransformation of progesterone.

\subsection{Effect of substrate concentration on} progesterone bioconversion

The utilization of high amounts of the steroidal substrates is one of the important factors affecting the economy of the transformation process. Increasing concentrations of progesterone to (20 $\mathrm{mg} / 50 \mathrm{ml}$ ) retarded cortexolone and cortisol (Table 4). The optimum substrate concentration which gave the maximum bioconversion efficiency was $5 \mathrm{mg} / 50 \mathrm{ml}$ medium when added in the batch. This may be due to the toxicity of the substrate (progesterone) on the activity of the microorganism which took place by using large amounts of substrate concentration dissolved in $1 \mathrm{ml}$ of absolute ethanol which in turn may inhibit the growth of the microorganism (Adham et al., 2003). The same phenomena were recorded by Constantinides(1980), Goetschel and Bar (1992)and Arinbasarova et al. (1996).

\subsection{Effect of surface active agents}

Since transformation occurs when the dissolved steroids diffuse through the fungal cell wall into the enzyme and rich interior, it was important to evaluate the role of some surface active agents on the hydroxylation of progesterone. The addition of Tween 60 at concentrations 50 and $100 \mu 1 / 50 \mathrm{ml}$ medium and Tween 80 at conc $50 \mu 1 / 50 \mathrm{ml}$ medium exerted an appreciable increase in the rate of progesterone transformation while treatments exerted no effect on the bioconversion process. These results are in disagreement with Mohamed and Abd El Hadi, (2010) who found that tween 20 increased the bioconversion efficiency to $80 \%$ but Tween 60 and 80 decreased the bioconversion of progesterone. Similar results were recorded by Sallam et al.( 1995).

\subsection{Amino acids}

The amino acids : cysteine, L.asparagine and L.leucine were added individually to the fermentation medium to study their effect on the bioconversion process.Results illustrated in Fig. (6) showed that, L. asparagin increased the yield of cortisol to $66.36 \%$ compared to the control where bioconversion was $63.2 \%$, while other amino acids showed inhibitory effects on the bioconversion process. Daba( 2009) found that L.Leucine is the best amino acid for the bioconversion of cortexolone to the cortisol by Curvularia lunata RCMB 019001.

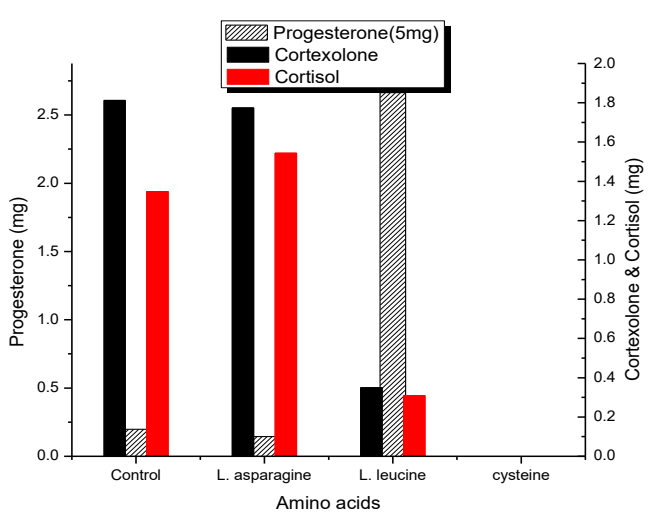

Fig. (6): Effect of amino acids on bioconversion of progesterone to cortexolone and cortisol. 
Table (2): Effect of inoculum size of Curvularia lunata RCMB 019002 on bioconversion of cortexolone to cortisol.

\begin{tabular}{|c|c|c|c|c|}
\hline $\begin{array}{c}\text { Inoculum size } \\
(\mathbf{m l} / 50 \mathrm{ml} \\
\text { medium })\end{array}$ & $\begin{array}{c}\text { Residual } \\
\text { progesterone } \\
(\mathbf{m g})\end{array}$ & $\begin{array}{c}\text { Cortexolone } \\
(\mathbf{m g})\end{array}$ & $\begin{array}{c}\text { Transformation products } \\
(\mathbf{m g})\end{array}$ & $\begin{array}{c}\text { Bioconversion } \\
\text { Efficiency }(\%)\end{array}$ \\
\hline 1 & 5.506 & 1.122 & $\mathbf{0 . 1 4}$ & 12.62 \\
\hline 2 & 4.88 & 1.272 & 0.80 & 18.77 \\
\hline 3 & 5.76 & 1.536 & $\mathbf{0 . 3 4 1}$ & 20.72 \\
\hline 4 & 4.54 & 1.5 & 1.184 & 26.84 \\
\hline $5^{*}$ & 3.93 & 2.012 & 1.760 & 37.72 \\
\hline 6 & 3.412 & 2.372 & 1.470 & 38.42 \\
\hline 8 & 3.300 & 2.380 & 1.570 & 39.50 \\
\hline 10 & 3.136 & 2.638 & 1.606 & 42.44 \\
\hline 15 & 2.45 & 2.860 & 2.690 & 55.50 \\
\hline 20 & 3.3 & 2.144 & 2.262 & 44.26 \\
\hline
\end{tabular}

*control

Table (3): Effect of culture age of Curvularia lunata RCMB 019002 on bioconversion of progesterone to cortexolone and cortisol.

\begin{tabular}{|c|c|c|c|c|}
\hline \multirow[b]{2}{*}{ Culture age (Day) } & \multirow{2}{*}{$\begin{array}{c}\text { Residual } \\
\text { progesterone } \\
\text { (mg) }\end{array}$} & \multicolumn{3}{|c|}{ Transformation product (Cortisol) } \\
\hline & & $\begin{array}{c}\text { Cortexolon } \\
(\mathrm{mg})\end{array}$ & $\begin{array}{c}\text { Cortisol } \\
(\mathrm{mg})\end{array}$ & $\begin{array}{l}\text { Bioconversion } \\
\text { Efficiency (\%) }\end{array}$ \\
\hline $1^{*}$ & 2.450 & 2.860 & 2.690 & 55.50 \\
\hline 2 & 2.421 & 2.992 & 2.873 & 58.65 \\
\hline 3 & 2.884 & 2.650 & 2.084 & 47.34 \\
\hline 5 & 3.541 & 2.224 & 1.063 & 32.87 \\
\hline 7 & 5.886 & 2.008 & 0.516 & 25.24 \\
\hline
\end{tabular}

*control

Table (4): Effect of different substrate concentrations on bioconversion of progesterone to cortexolone and cortisol by Curvularia lunata.

\begin{tabular}{|c|c|c|c|c|}
\hline \multirow{2}{*}{$\begin{array}{c}\text { Substrate conc. } \\
(\mathrm{mg} / 50 \mathrm{ml} \text { medium })\end{array}$} & $\begin{array}{c}\text { Residual } \\
\text { progesterone } \\
(\mathrm{mg})\end{array}$ & $\begin{array}{c}\text { Cortexolone } \\
(\mathrm{mg})\end{array}$ & $\begin{array}{c}\text { Cortisol } \\
(\mathbf{m g})\end{array}$ & $\begin{array}{c}\text { Transformation products } \\
\text { Efficiency }(\%)\end{array}$ \\
\cline { 3 - 5 } & $\mathbf{0 . 1 9 8}$ & 1.812 & 1.348 & 63.2 \\
\hline 5 & 0.311 & 2.61 & 3.124 & 61.2 \\
\hline 7.5 & 2.421 & 2.992 & 2.873 & 58.65 \\
\hline 10 & 3.220 & 2.776 & 2.594 & 35.80 \\
\hline 20 & 4.67 & 2.718 & 1.502 & 28.13 \\
\hline
\end{tabular}

*control

Table (5): Effect of some surface active agents on the bioconversion of progesterone by Curvularia lunata.

\begin{tabular}{|c|c|c|c|c|}
\hline \multirow[b]{2}{*}{ Additive conc. In $\mu \mathrm{l}$} & \multirow{2}{*}{$\begin{array}{c}\text { Residual } \\
\text { progesterone } \\
\text { (mg) } \\
\end{array}$} & \multicolumn{3}{|c|}{ Transformation Products } \\
\hline & & $\begin{array}{l}\text { Cortexolone } \\
\text { (mg) }\end{array}$ & $\begin{array}{c}\text { Cortisol } \\
\text { (mg) }\end{array}$ & $\begin{array}{l}\text { Bioconversion } \\
\text { Efficiency (\%) }\end{array}$ \\
\hline Control & 0.198 & 1.812 & 1.348 & 63.64 \\
\hline \multicolumn{5}{|c|}{ Tween 60 : - } \\
\hline 50 & 0.173 & 1.820 & 1.425 & 64.9 \\
\hline 100 & 0.166 & 1.886 & 1.449 & 66.70 \\
\hline 150 & 0.333 & 1.540 & 1.400 & 58.80 \\
\hline \multicolumn{5}{|c|}{ Tween 80 : - } \\
\hline 50 & 0.154 & 1.890 & 1.592 & 68.64 \\
\hline 100 & - & - & - & - \\
\hline 150 & - & - & - & - \\
\hline
\end{tabular}

*control ( without additives) 


\section{REFERENCES}

Adham N.Z., Ahmed A.A. and Naim N. (2003). Biochemical studies on the microbial $\Delta^{1}$ dehydrogenation of cortisol by Pseudomonas fluorescens. Process Biochem., 38: 897-902.

Arinbasarova A.Yu., Karpov A.V., Fokina V.V., Medentsev A.G. and Koshcheyenko K.A. (1996). Kinetic characteristics of 1-endehydro-genation of $6 \quad \alpha$-methyl hydrocortisone by cells of Arthrobacter globiformis 193. Enzyme Microb. Technol., 19(7): 501-506.

Breskvar K. and Hundik-Plevnik T., (1981). Inducibility of cytochrom $\mathrm{P} 450$ and $\mathrm{NADPH}$-cytochrome $\mathrm{C}$ reductase in progesterone treated filamentous fungi Rhizopus nigricans and Rhizopus arrhizus.

J. Steroid Biochem., 14: 395-399.

Chincholkar S.B., Laxman R.S. and Wakharkar R.D., (1995). Hydroxylation of progesterone by $C$. blakesleeana NCIM 687. World J Microbiol. Biotechnol., 11(3): 357-358.

Constantinides A. (1980). Steroid transformation at high substrate concentrations using immobilized Corynebacterium simplex cells. Biotechnol. Bioeng., 12: 119 .

Daba G.A. (2009). Microbial transformation of cortexolone to cortisol by fungi., M.Sc. Thesis, Faculaty of Science , Ain Shams University.

El-Kadi I. A, and Mostafa E. M. (2004). Hydroxylation of progesterone by some Trichoderma species. Folia Mictobiol. 49 (3), 285-290.

El-Refai H.A, Sallam L.A.R. and El-Kady I.A. (1969). Microbiological transformation of progesterone. J. Gen. Appl. Microbiol. 15: 301-307.

Farooq A, Hanson J.R. and Iqbal Z. (1994). Hydroxylation of progesterone by Cephalosporium aphidicola. Phytochemistry., 37(3):723-726.

Fernandes P,Cruz A, Angelova B, Pinheiro H.M. and Cabral J.M.S. (2003). Microbial conversion of steroid compounds: Recent developments. Enzyme Microb. Technol., 32: 688-705.

Fouad W.A., Abbas I.H., Elwan K.M., Swellum M.A. and El-Dougdoug Kh.A. (2009). Biotransformation of progesterone by microbial steroids. Journal of Applied Sciences Research, 5(1): 137-143.
Goetschel R. and Bar R. (1992). Formation of mixed crystals in microbial conversion of sterols and steroids. Enzyme Microbiology. Technol., 14:462-9.

Krasnova L. A, Messinova O. V, Baynova V. I, Kolyvanova T. S. and Grinenko G. S. (1987). Cited in current trends in microbial steroid biota as formation. Russian Patent $801,517$.

Manosroi J, Saowakhon S. and Manosroi A. (2008). Enhancement of $17 \alpha$ hydroxyprogesterone production by biotransformation using hydroxypropyl- $\beta$ cyclodextrin complexation technique. Journal of Steroid Biochemistry \& Molecular Biology., 112:201-204.

Martin D.A.G. (2010). Biotransformation reactions by Rhizopus spp. Current Organic Chemistry., 14: 1-14.

Meggs R, Muller-Frohne M., Pfeil D. and Ruckpaul K. (1990). Microbial steroid hydroxylating enzymes in gluco-corticoid production. In: Ruckpaul, K. and Rein, H. (Eds.), Frontiers in Biotransformation. Academie- Verlag, Berlin, pp. 204-243.

Mohamed S.S. and Abd-El Hadi A. (2010). One step production of $11 \alpha$-hydroxy progesterone, hydrocortisone and prednisolone from progesterone by Mucor racemous NRRL 3631. International Journal of Academic Research, 2: 124-130.

Nelson D.R., Kamataki T, Waxman D.J., Guengerich F.P., Estabrook R.W., Feyereisen R.M., Gonzalez F.J., Coon M.J., Gunsalus I.C., Gotoh O., Okuda K. and Nebert D.W. (1993). The P450 superfamily: update on new sequences, gene maping, accession numbers, early trivial names of enzymes and nomenclature. DNA and cell biology., 12:1-51.

Parasckiewicz K. and Dlugoński J. (1998). Cortexolone 11 $\beta$-hydroxylation in protoplasts of Curvularia lunata. J. Biotechnol., 65: 217-224.

Sallam L.A.R., El-Abyad M.S.,El-Refai A.H., El-Menofi H.A. and Adham N.Z. (1995). Bioconversion of 19-noitestosterone by Rhodococcus sp. DSM 92-344.1: Optimization of transformation parameters. Process Biochem., 30(1): 25-34.

Stephanie R. B. (2006). Updates in Therapeutics for Veterinary Dermatology. Veterinary Clinics of North America., 36(1): 39-58.

Templeton J. F., Kumar V. P., Sashi I., Marat K. Kim R. S., Labella F. S. and Cote D. 
(1987). J. Nat. Prod. 50, 463.

Vitas M., Smith K., Rozman D. and Komel R. (1994). Progesterone metabolism by the filamentous fungus Cochliobolus lunatus.J. Steroid Biochem. Molec. Biol. 49: 87-92.

Vitas M., Rozman D., Komel R. and Kelly L.S. (1995). P450 mediated progesterone hydroxylation in Cocohliobolus lunatus. Journal of Biotechnology., 42: 145-150.

Voigt B., Porzel A., Naumann H.,
Horholdschubet C. and Adam G. (1993). Hydroxylation of the native brassinosteroids 24-epicastasterone and 24-epibrassinolide by the fungus Cunninghamella echinulata. Steroids, 58(7): 320-323.

Waldi D. (1965). Thin layer Chromatography. A Laboratory Handbook, pp. 249. Engon Stahl (Ed.). Academic Press Inc., New York, London.

$$
\begin{aligned}
& \text { دور بعض العوامل فى التحول الميكروبي البروجيستيرون الى كورتيكسولون وهيدروكورثيزون } \\
& \text { حسان امين عبد المجيد المنوفى- منى سيد شافعى - *محه مدحت غريب - رانيا عبد الرازق عبد العال } \\
& \text { قسم كيمباء المنتجات الطبيعية و الميكروبية ـ المركز القومى للبحوثـ الجيزة } \\
& \text { *قم النبات - كلية العلوم- - جامعة المنوفية - المرية }
\end{aligned}
$$

ملخص

اختبرت كفاءة اربع عزلات فطرية لتحويل مركب البروجيستيرون وثبت فاعلية الفطريات المختبرة لإجر اء التفاعل ملت

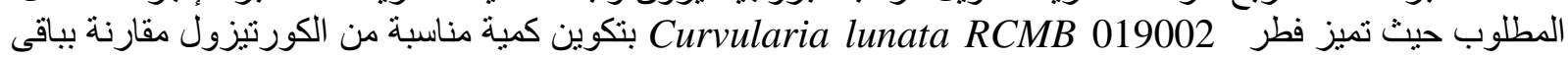

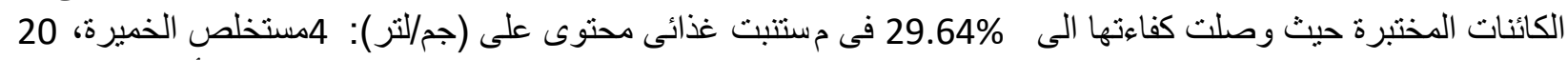
malt extract الذى اعطى اعلى نسبة تحول بعد 48 ساعة من مركب الكورتيكسولون وكورتيزول حيث تأثرت عملية التحويل بدرجة الأس الهيدروجينى للمستنبت الغذائى المستخدم ووجد ان افضل عملية تحويل تم الحصول عليها باستخدام درجة أس هيدروجينى 7 باستخدام buffer solution حيث وصلت التئ الى

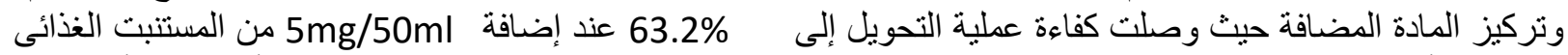

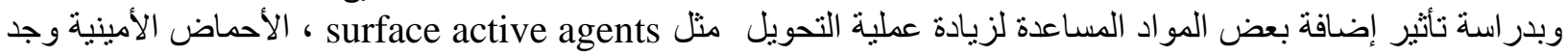

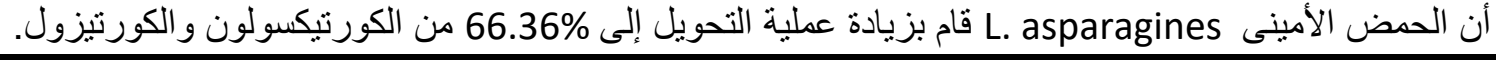

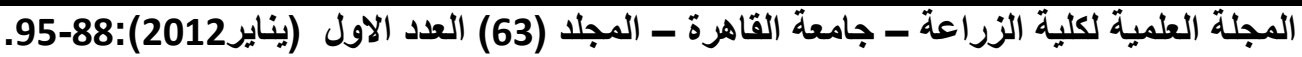

